\title{
The Historical and Philosophical Foundations of Conservative Educational Policy
}

\author{
James Percival, Oxford Brookes University
}

\begin{abstract}
Contemporary Conservative education policy may seem to be hastily formulated and executed, but it is arguedly founded on deeply held ideological beliefs. By briefly examining the history of the British Conservative party, including its complex formation and disparate ideological traditions, including the broader conservative diaspora, four key elements of Conservative educational beliefs, namely support for traditional practices, antiintellectualism, economic liberalism and the power of the market, and support for inequalities of outcome, are discussed. These beliefs are then examined against contemporary policy initiatives such as practice based teacher training, the marketisation of schools and curriculum reform.
\end{abstract}

For academics still engaged in university-based teacher training it is quite common to hear the refrain that the current (2010 onwards) Conservative administration is simply making up educational policy as it goes along. This is certainly the sense one gets when a government White Paper outlining a plan to convert all state schools into academies by 2022 (DfE, 2016) is then rescinded within days (Adams, 2016); but what this paper argues is that the Conservative government is actually reflecting a number of deeply held ideological principles which can be identified from an examination of the history of the party. That stated, two important qualifications need to be made. To begin with the small c 'conservative' diaspora is obviously much broader than the Conservative and Unionist party which was founded in 1832 under the leadership of Robert Peel (Blake, 1970), and includes writers and philosophers from outside the party; secondly, one of the claims Conservatives make about themselves is that they are non-ideological (Gilmour, 1977), even 'anti-theory', and therefore ideology is a word that has to be applied judiciously. Nevertheless, a number of important unifying beliefs can be identified.

Hugh-Cecil (1912) argued that the Conservative party that had developed by the end of the $19^{\text {th }}$ century, particularly under the leadership of Disraeli, was an amalgamation of both Tory and Whig political movements. Both parties were broad coalitions: the Tory party has 
generally been defined as the party of the shires, the gentry (the so called 'squirearchy'), high church (with Catholic sympathies) and a strong belief in tradition and order (Huntingdon, 1957). The Whig party, by contrast, was arguably a broader coalition which included religious non-conformists, the great land owning aristocrats (oligarchs), and the increasing influence of factory owners and capitalists. It also supported practical and empirical forms of reasoning (what has worked) in opposition to some of the more radical and intellectual ideas associated with the Enlightenment. Both parties identified with Edmund Burke's Reflections on the Revolution in France (1790) and the dangers of the application of pure reason to government and society; and both also favoured the principles of tradition, the reform of existing institutions, rather than radical change, and government by consent.

By the end of the $19^{\text {th }}$ century, having combined most capital, wealth and the social elites within the Conservative party, Disraeli took the organic, hierarchal and empirical aspects of Tory and Whig thought to create something he described in a 1872 speech as 'one nation' (Blake, 1966). This was essentially based on the ideas of common sense allied to paternalism and pursuit of a common good - though admittedly with very unequal claims to wealth, power and influence. Arguably one-nationism was the party's guiding principle for much of the $20^{\text {th }}$ century, and it latterly included support for social welfare and limited economic redistribution. However, since the 1970s the Conservative party has also been influenced by the international movement that has often been termed the 'new right'. According to Honderich (1990) this movement is self-avowedly more intellectual, conceptual and ideological than traditional conservatism, and it can be further delineated between the neoconservatives, influenced by Hayek (1944), who combine arguments for free market economics, alongside high levels of authority and state interventions to maintain traditional and religious values; and the neo-liberals (also termed libertarians), for example Nozick (1974), who have argued for limited state legitimacy in any sphere of influence. Nevertheless, all theorists from a new right perspective believe in the superiority of market forces combined with high levels of competition.

Just how broadly conservatism can be defined is illustrated by this adaptation of Dunleavy and O'Leary's $(1987, \mathrm{p} .8)$ four quadrants of state intervention: 


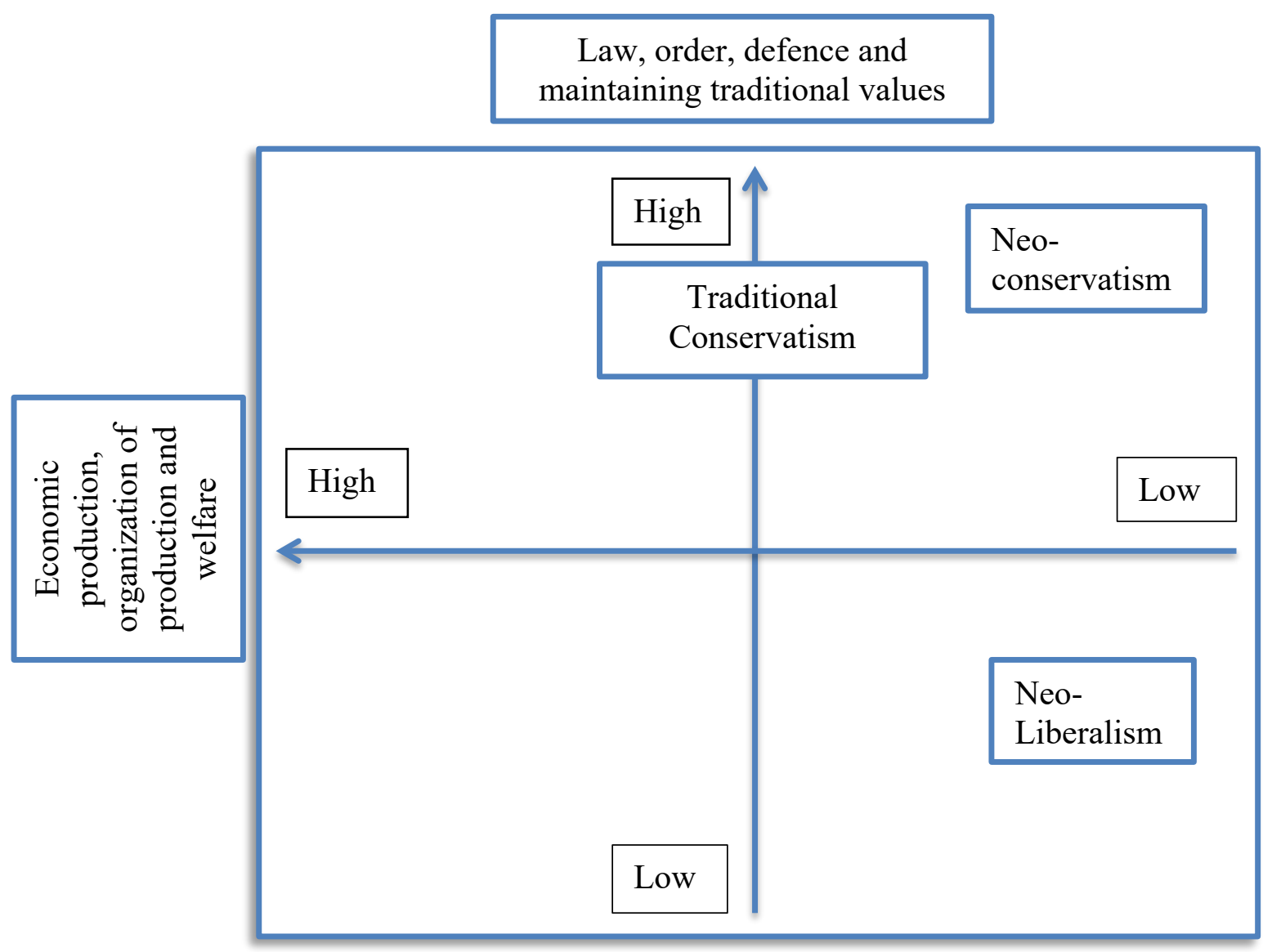

This disparate set of influences may make the Conservative Party difficult to pin down, but also flexible and adaptable when it comes to policy. Nevertheless there are some core educational beliefs. To begin with Conservatives ultimately wish to conserve and therefore they have a naturally tendency to favour educational 'traditions', for example drawing from empirical evidence of what has worked, what continues to work, and what has traditionally been valued by important stakeholders. This is combined with a long-standing suspicion of educational theory and expertise. Michael Gove, as the chief architect of policy between 2010 and 2015, was vocal in his dismissal of educational experts. (Indeed, he was even more dismissive of the economic experts who warned against Brexit). A key influence on Gove, the philosopher Michael Oakeshott (1962), argued that theory is only useful when it can be linked to measurable outcomes and allied to practical instruction (1947). A belief in economic liberalism and the power of market forces is also shared by most conservatives, and therefore an educational model based on competition allied to a focus on educational outputs, rather than the previous concerns with inputs and investment, has predominated in 
Conservative administrations since 1979 (Apple, 2001). It should also be recognised that conservatives do not necessarily believe in equality in any form, other than rather vague Tory notions of a purely formal sense of equality in the sight of God or basic rights in civil law. While aspects of the new right are keener on notions of equality of educational opportunity (though certainly not equalities of outcome), it is reasonable to claim that the majority of conservatives, for example Hailsham (1959) and Scruton (1984), believed that people are not equal in temperament, judgement, intelligence or aptitude, and that attempts to engineer greater educational (and social equality) would be doomed to failure, and deeply illiberal. An acceptance of inequality also tends to be combined with a deeply held belief in authority and hierarchies of control (Greenleaf, 1964).

In terms of ideology in action, three recent policy initiatives can be analysed against this schema. Since the publication of the White Paper 'The Importance of Teaching' (2010), the responsibility for initial teacher training (ITE) has increasingly been taken out of the hands of higher education institutions and placed into schools. Although the variety of possible routes to gain qualified teacher status (QTS) are now Byzantine in their complexity, the essential message Gove (2010) presented was that schools are better equipped to support trainee teachers in learning the 'craft' of teaching than university based 'experts'. This is not a new belief: in the early part of her first administration Margaret Thatcher supported interventions to reduce the amount of theory contained in teacher training courses, and a corresponding increase in placements. However, she had more pressing economic and social concerns to occupy her, and so it fell to Cameron's government to fully enact this policy. Moreover the whole question of the status of teaching and whether a formal qualification is required has been mooted, and the waters muddied by the right of academies and free schools to appoint unqualified teachers, even non-graduates. Despite the fact that this policy reverses the increasing trend towards professional qualifications in many occupations, it is arguably grounded in three core conservative beliefs. Most Conservative politicians have either been privately educated, or would aspire to educate their own children privately, and it is well known that independent schools often appoint unqualified teachers, and non-graduates in some areas, and yet they dominate educational league tables. Moreover, many of these school scan trace their origins to long before the state system began. For Conservatives this is clear evidence that traditions of educational success demonstrate that gaining QTS is itself no guarantee of high quality teaching standards, and therefore it is better to be guided by what has worked (empiricism and tradition) than educational expertise. This, naturally, leads to the 
second belief that educational theory's role in ITE has very little value because it is disembodied from the practical concerns of teaching and learning, and without clear and measurable evidence of the success and impact of theory based teacher training. Hence the belief that policy should be guided by evidence of what has worked and continues to work, therefore practical, school based learning is deemed more efficacious. It also draws from the core belief that core knowledge is more important than theory, and here it is possible to be sympathetic since research does suggest that the knowledge and expertise that teachers bring to the classroom is a good indicator of their impact on learning (Barber, M., \& Mourshed, M, 2007; Klassen, 2016). So recruiting the best candidates, irrespective of the training they receive, is arguably a reasonable policy. The weakness with this approach is that there is scant evidence that recent initiatives have attracted or retained the best candidates, nor that schools are providing consistently good teaching apprenticeships.

Curriculum reforms have also reflected core ideological beliefs. Influenced by Hirsch (1988), Gove's first act as secretary of state in 2010 was dismiss Rose's revised curriculum which reflected the movement towards more subject integration and creative approaches to the curriculum; Gove (2009) had previously stated his belief in the importance of separate subject teaching, and he then formulated a revised national curriculum (DfES, 2013) which introduced far more content into primary schools alongside autocratic and strictly monitored instructions for the teaching of reading based on synthetic phonics and the increased role of rote learning in mathematics, while secondary schools were faced with the removal of course work elements in final examinations. Much of the work to raise the status on vocational qualifications for the key 14-18 sector, were reversed; for example the recommendations of Tomlinson Report (2004) were replaced by the Wolf Report (2011) and the language of 'basic skills', 'new apprenticeships', 'crafts' and 'trades'. Young (2011, p273) rightly questioned who would use this sort of archaic language other than Michael Gove, but the message was clear: academic knowledge trumps practical skills, and that children ought to be segregated into either academic or vocational streams. Here we can detect the hierarchies and inequalities of academic attainment and a strong whiff of social class. We can also detect the core belief in traditional forms of knowledge and the irony of preparing children for employment in the $21^{\text {st }}$ century by looking back to the practices of the $19^{\text {th }}$ century (White, 2011). 
Even though the academy programme was introduced by the previous Labour administration, although initially restricted to either struggling or highly successful schools, this policy, clearly based on free market principles, has been adopted with relish by the current Conservative government. The academy programme has been expanded and conjoined with the policy for interested parties to bid for funding to create free schools. It is clearly a prima facie example of the influence of new right ideology supporting the idea of parental choice. It is also a policy that could easily have been predicted based on a raft of previous initiatives, not least the introduction of league tables for schools, that was clearly meant to separate the wheat from the chaff; while newly released government papers indicated that Thatcher intended the free market for schools to happen early on in her administration (Berg, 2014). Differentials in pay and conditions are already starting to create a free market for teachers, mirroring some of the aspects of practice in private schools. This should be no surprise for what we are now seeing is the beginning of a state funded, independent school system; the strong shall survive, and presumably expand through franchises, and the weak will theoretically close. But will this happen in deprived areas where strong schools are needed most? Ironically it is the exact reversal of the policy after the 1902 act where failing independent schools requested entry into the state system to survive. Yet arguably the biggest conundrum surrounds the rhetoric of success and failure. As Taylor (2015) argued, all schools must be seen to improve and be 'above average', while higher results only confirm an erosion of standards. The thorny conservative belief in selection, thus reinforcing inequalities of provision and opportunity, has re-emerged (Coughlan, 2016) and has recently been outlined in September 2016's green paper (Dickens, 2016). Yet in many respects the market for schools has already created an unofficial selective system with middle class parents moving to the catchment area of oversubscribed, successful state schools, and thus thwarting the social mobility that Gove, in a RSA speech from 2009, stated as one of his purported priorities.

Ultimately, however, apart from genuine mavericks like Gove, do the majority of small and large 'c' conservatives really desire a very high performing state system and high levels of social mobility? It is hard not to conclude that for many conservatives the state system is ultimately meant to produce biddable young people suitable for relatively low status employment and ready to take their place as economically productive members of society; but in no sense, apart for a small number of exceptions, should state schools challenge the 
hegemony of the independent sector and its access to top universities and high ranking careers.

\section{References}

Adams, R. (2016, 01/08/2016). Government drops plan to make all schools in England academies Retrieved 01/08/2016, 2016, from

https://www.theguardian.com/education/2016/may/06/government-backs-down-overplan-to-make-all-schools-academies

Apple, M. W. (2001). Comparing Neo-Liberal Projects and Inequality in Education. Comparative Education, 37(4), 409-423.

Barber, M., \& Mourshed, M. (2007). How the World's best-performing school systems come out on top (pp. 56). London: McKinsey \& Company.

Berg, S. (2014). Margaret Thatcher explored education overhaul, archives show Retrieved 27/07/2016, 2016, from http://www.bbc.co.uk/news/uk-30625941

Blake, L. (1966). Disraeli. London: Eyre \& Spottiswoode.

Blake, L. (1970). The Conservative Party from Peel to Churchill. London: Fontana.

Burke, E. (1790). Reflections on the Revolution in France. London: Penguin Classics.

Coughlan, S. (2016, 28/07/2016). Are grammar schools about to make a comeback? , from http://www.bbc.co.uk/news/education-36884563

Department for Education (DfE). (2010). The Importance of Teaching. (ID P002401441 11/10). London: HMSO.

Department for Education (DfE). (2016). Educational Excellence Everywhere. (ID P002796898 03/16). London: Open Government Licence, HMSO.

Dickens, J. (2016). Grammar schools green paper: The 12 policy recommendations. Schools Week (September 12th 2016).

Dunleavy, P., \& O'Leary, B. (1987). Theories of the state: the politics of liberal democracy. Basingstoke: Macmillan Education.

Gilmour, I. (1977). Inside Right (A Study of Conservatism). London: Quartet Books.

Gove, M. (2009). What is Education For? Speech by Michael Gove MP to the RSA 29th June 2009. https://www.thersa.org/globalassets/pdfs/blogs/gove-speech-to-rsa.pdf

Gove, M. (2010). Speech - Michael Gove to the National College Annual Conference, Birmingham. London. https://www.gov.uk/government/speeches/michael-gove-tothe-national-college-annual-conference-birmingham

Greenleaf, W. H. (1964). Order, Empiricism and Politics (Two Traditions of English Political Thought). Oxford: Oxford University Press.

Hailsham, V. (1959). The Conservative Case (second revised ed.). London: Penguin.

Hayek, F., A. (1944). The Road to Serfdom. London: Routledge.

Hirsch, E. D. (1988). Cultural Literacy: what every American needs to know. New York: Vintage Books.

Honderich, T. (1990). Conservatism. London: Penguin.

Hugh-Cecil, L. (1912). Conservatism. London: Williams \& Norgate.

Huntington, S. P. (1957). Conservatism as an Ideology. American Political Science Review, 51(2), 454-473.

Klassen, R. (2016). Can you spot a good teacher from their characteristics. York University Magazine(2), 32-34.

Nozick, R. (1974). Anarchy, State, and Utopia. Oxford: Blackwell.

Oakeshott, M. (1947). Rationalism in Politics. In T. Fuller (Ed.), Rationalism in Politics (And other Essays) (pp. 5-42). Indianapolis: Liberty Press. 
Oakeshott, M. (1962). On Being Conservative. In T. Fuller (Ed.), Rationalism in Politics (And other Essays) (pp. 407-437). Indianapolis: Liberty Press.

Scruton, R. (1984). The Meaning of Conservatism (Second ed.). London: MacMillan.

Taylor, P. (2015). All Above Average: secondary school improvements as an impossible endeavour. Forum, 57(2), 239-249.

Tomlinson, M. (2004). 14-19 Curriculum and Qualifications Reform - Final Report of the Working Group on 14-19 Reform. ((Ref: DfE-0991-2004)). Annesley, Nottingham: DfES Publications.

White, J. (2011). Gove's on the bac foot with a white paper stuck in 1868, Times Educational Supplement.

Wolf, A. (2011). Review of Vocational Education. London: HMSO.

Young, M. (2011). The return to subjects: a sociological perspective on the UK Coalition government's approach to the 14-19 curriculum. The Curriculum Journal, 22(2), 265-278. 